Mr. Knobel's statement that with one exception he has " personally examined; every paper or book to which reference is made," will afford an idea of the expenditure of time and trouble involved in the production of his catalogue. By the way, the one exception refers to the "Sidereal Messenger," issued by the late Prof. O. M. Mitchell, while director of the Observatory at Cincinnati, which Mr. Knobel says is "not in the British Museum nor the libraries of the Royal Society and the Royal Astronomical Society." The writer is able to testify to a circumstance from his own experience, which may throw some light on the rarity of this periodical in our scientific libraries. He was one of a favoured few in this country to whom Prof. Mitchell sent the "Sidereal Messenger." It arrived through the post in one or more numbers at a time, but the postal arrangements with the United States not being then on the liberal footing of the present day, and Prof. Mitchell unluckily enveloping his journal in a stiff cover, heavy letter-postage was demanded for the successive deliveries. The demand increased on each occasion, until the presentation of one, which would have left but small change out of a sovereign, closed the writer's knowledge of the "Sidereal Messenger," and he has some recollection that the present Plumian Professor of Astronomy informed him at the time that his own receipt of the paper terminated about the same epoch, and for a similar reason. If this be a mistake, perhaps the periodical to its termination may be found in the library of the Cambridge Observatory. No. 4 contains the author's early measures of the companion of Antares, which he detected at Cincinnati, in 1845 , with measures of $\eta$ Corono and one or two other double stars of no particular interest. The "Sidereal Messenger" was not continued for any length of time.

\section{METEOROLOGICAL NOTES}

Climate of Manitoba. - In the foumal of the Austrian Meteorological Society for October 1 , there appears a valuable paper on this subject by Dr. A. Wojeikoff, based on observations made for a periad of about five years at Winoipeg, the capital of this province of Canada. The results, a monthly résumné of which accompanies the paper, show a mean atmospheric pressure about three-tenths "of an inch less in summer than in wirter, and in consequence of the position of Manitoba with reference to the diminished pressure in the interior of the continent at this season, N. and N.W. winds prevail there ig per cent. less, and N.E. E., S., and W. winds 26 per cent. more in summer than in winter. Leaving out September, the rainfall of which appears to be exceptional, May and June are the two rainiest months, and next to these come April and July, the rainfall of Winnipeg being in these respects closely analogous to that of the prairie region of the Western States. The rainfall for the year is only 22 inches. The greatest amount of cloud and the greatest relative humidity occur in November. The mean annual temperature is $34^{\circ} \circ$, the coldest month January, being $0^{\circ} .5$, and the warmest July, $66^{\circ} \%$. The winter temperature is thus as cold as that of Archangel, but the summer temperature as warm as that of Paris. The high summer temperature and generous rainfall from April to July, the rainfall rising from $\mathrm{r} \cdot 85$ inches in April to $3.5^{8}$ inches in June, mark the climate of Manitoba as admirably suited for the successful cultivation of wheat, barley, potatoes, turnips and other agricultural products of temperate regions. Dr. Wojeikoff draws an interesting comparison between the climates of the prairies of Manitoba and Minnesota on the one hand, and the Steppes of Western Siberia on the other, and shows that the seasonal distribution of temperature of Winnipeg is all but identical with that of Ischim, and that of St. Paul with Saratow. An important climatic difference must, however, be kept in view, viz., the summer rains are several weeks earlier in Manitoba than in Siberia.
Sirocco AT PAU. - In the same number M. Piche, Secretary of the Meteorological Commission of the Lower Yyrenees, communicates a short notice of a sirocca which occurred in that part of France on September 1,1874 , during which the temperature rose at Biarritz to $x_{0}{ }^{\circ} 3$, and the humidity fell to 38 , the humidity falling still lower, or to 33 , at Eaux-Bonnes. The extraordinary heat and dryness of the sirocco, which came from the south and south-east are attributed by M. Piche to the course it had pursued, that course being from Africa, across the Pyrenees, and thence down on Pau, this wind being thus quite analogous to the fön of the Alps. The sirocco of the Lower Pyrenees being merely the in-draught towards a low atmospheric pressure accompanying a great storm which is advancing from the west, it follows that as soon as the wind veers to W. or to N.W., and consequently no longer crosses the Pyrenees before reaching Pau, it may be expected that the air will become instantly saturated with moisture, and rain begin to fall. This is just what takes place, and the connection betwreen the sirocco and Atlantic storms is well recognised, and finds expression in the weather-prognostic current at Pau, "The drier the air the nearer the rain."

The Norivegian Atrantic Expedition.-Prof. Mohn communicates to the Bulletin International an interesting note on the Norwegian scientific cruise of last summer. The hourly meteorological observations will not only be discussed with a view to ascertain the diurnal periods during the summer months, but also be compared with simultaneous observations made on land with the view of tracing the connection which subsists between the weather and its changes on sea and land respectively In addition to the observations usually made on board the navy of Norway, the humidity of the air, the evaporation from seawater, the velocity of the wind, and the rainfall were observed. The zoological collection is rich and varied, many of the species found are new to science, and will necessitate the establishment of new genera. A valuable collection has been made of specimens of the sea-bottom taken at each sounding, of sea-water from the bottom and the surface, and of the rocks and minerals of Farö and Westmanna Island. The stoimy character of the weather prevented magnetic observations being made on board, but such observations were very carefully made at Musö, in Sognefiord, Reykjavik, and Namsos in Norway. The expense of the cruise, inclusive of the instruments and apparatus, has been 165,000 franes-an expenditure which can only be regarded as liberal for such a country as Norway-and it is intimated to be the intention of the Norwegian Government to resume the prosecution of the researches in the next two years, extending them in the direction of Jan Magen and Spitzbergen.

Barometers of Southern Russia. - M. Moritz, the eminent director of the Tiflis Observatory, makes an important communi cation to the Bulletin International of October 26, regarding the barometers of the stations in the south of Prussia. Prof. Wild, in the Annals of the Central Physical Ubservatory of St. Peters. burg for 1874 , states that the barometer at Tiflis is 0.028 inch lower than that at Nicolaieff. The determination of the true aifference of the readings of these two barometers is of more importance than appears at first sight, because the barometers of all the Russian stations on the borders of the Black Sea have their errors determined by that of the barometer at Nicolaieff, or as it is technically phrased, are controlled by it, whereas all the barometers of the Caucasian Stations are controlled by that of Tiflis. Now these southern Russian Stations, taken as a whole, can supply data, unique of its kind, towards the solution of such questions of general meteorology as concerns the influence of large sheets of water and lofty mountain ranges on the state of the atmosphere and its movements, if only we be quite certain that the barometric readings at the numerous stations over the region are comparable with each other. During the past summer M. Moritz has made a careful comparison of the Tiflis 
and Nicolaieff barometers, by means of two barometers which he carried from Tifls to Nicolaieff, and back again to Tiflis, with the result that the difference between the two barometers by which so many barometers are controlled, is only a tenth part of the difference as given by Prof. Wild, or the difference instead of being 0.028 inch, is only 0.003 inch. The comparison of station barometers is a laborious and delicate operation. If the instrument be a Board of Trade barometer, having an air-trap, any air lodged in it renders the comparison worthless; if not furnished with an air-trap, any air admitted into the tube vitiates the comparison; and if care be not taken in hanging the barometers or in timing the observations so as to secure that each attached thermometer truly gives the temperature of the whole instrument with its contained mercury, the comparison is not satisfactory.

The Fall of Temperature in END OF OCTOBER.The weather maps of Europe of October 27 and following days show remarkable changes in the distribution of the atmospheric pressure and changes of temperature consequent thereon. On the 27 th pressures were much higher in the east than in the west of the continent, accompanied with south winds and temperatures considerably above the average of the season in Great Britain; in other words the meteorological conditions were analogous to those described in a recent number of NATURE (vol, xiv, p. 536), as characterising the warm weather from October 4 to 7 . On the 28 th, however, barometers began to fall in the extreme north of Norway. This depression and a general lowering of the barometer was propagated southwards over Eastern Europe, while at the same time barometers rose to a considerable height over Western Europe. The necessary result, as regards the British Islands, of this altered distribution of pressure was a change of wind from south to north and a fall of temperature from about $5^{\circ}$ above the average on October 27 and 28 , to about $5^{\circ}$ below it on October 31 and November 1 . In addition to the interest of this illustration from its bearing on the importance of a knowledge of the weather in the extreme north of Europe in connertion with weather forecasts for Great Britain, it is also interesting as a type of those meteorological conditions to which some of our severe winter weather is due. Indeed, some of our severest winter storms of wind and snow have occurred with barometric depressions which have advanced from the Arctic Sea southwards over Europe; and they are peculiarly severe in these islands when the centre of the depression takes a course more to westward than that of last week, or when it passes to the south-eastward over the North Sea or over Denmark.

\section{NOTES}

WE publish this week the complete Report of Capt. Nares on the Arctic Expedition, along with a new map showing in detail the various geographical discoveries made by the expedition, our map of last week being necessarily very general. We congratulate the Admiralty on the rapidity of the publication, and are glad to be able thus to place on permanent record the general report of the Commander of the expedition, both as to its work and its results. As we said last week, these results will be fully appreciated only when the various scientific reports are published. Of course various schemes have been proposed to accomplish the minor object in attempting to attain which our fearless men were baffled-the attainment of the Pole. A correspondent writes to us suggesting the use of a balloon to be inflated at the coal-bed in Discovery Bay, and crossing right over the Pole, about I,000 miles, obtain a bird's-eye view of what is below. A correspondent in one of the daily papers advocates the use of steam, and that something like a tramway should be made to the Pole, the floe-bergs being tunnelled if necessary. Another of our correspondents endeavours to show that the ice-masses met with must have been pushed over rom the Siberian coast, though this seems somewhat inconsistent with the fact of the destruction of the Behring Strait whaling fleet by ice. But what do all these groping ideas point to but the adoption of Weyprecht's scheme, ad vocated by the German Government, and curiously enough only now finding its way into the daily papers, as something before quite unknown here, though we published it in detail a year ago. If we are not mistaken we shall have to thank both the successes and the failures of this expedition for opening up a new era in Arctic exploration, The following promotions for services rendered in comection with the Arctic Expedition have been made:-Commander A. H. Markham to be Captain ; Lieutenants Pelham Aldrich, L. A. Beaumont, and A. A. C. Parr to be Commanders; SubLieutenant C. J. M. Conybeare to be Lieutenant; Staff-Surgeon B. Ninnis, M.D., to be Fleet Surgeon; Surgeons E. L. Moss, M.D., and R. W. Coppinger, M.D., to be Staff Surgeons; Engineers D. Cartmel and James Wootton, to be Chief Engineers; Assistant Paymaster Thomas Mitchell to be Paymaster.

As we announced last week, Capt. Allen Young has returned with the Pandora. He was so beset with ice in about $78^{\circ} \mathrm{N}$, that he was able to accomplish little, though he managed to deposit the letters and despatches which he took out for the expedition. Capt. Young found sone Eskimo at the high latitude of $77^{\circ} 12^{\prime} \mathrm{N}$., who conducted themselves very well. They offered Capt. Young's 'party everything they had, and when asked what they would like to receive, the chief went off to the ship and selected a 15 -foot ash oar and some gimlets. $\mathrm{He}$ wanted the oar for spear shafts, and the gimlets to bore ivory and bone in order to cut it. Some other usetul presents were given them, and they gave in exchange some narwhal's horns, specimers of their pot stone cooking kettles, and of the iron pyrites used for striking fire. Capt. Adams, the well-known master of the whaler Arctic, has brought home with him to Dundee an Eskimo "Chief" named Alnack, thirty-eight years old, who has for years bejsed to be taken to England. His object in coming to Dundee is that he may get during the winter, know ledge that might be of much importance to the tribe of which he is chief. We hope he will take more kindly to our climate and habits than previous Eskimo visitors.

THE following is the award of medals for the present year by the Council of the Royal Society :-The Copley Medal to Prof. Claude Bernard, For. Mem. R.S., for his numerous contributions to the science of physiology; a Royal Medal to Mr. William Froude, F.R.S., for his researches, both theoretical and experimental, on the behaviour of ships, their oscillations, their resistance, and their propulsion; a Royal Medal to Sir C. Wyville Thomson, F.R.S., for his successful direction of the scientific investigations carried on by H.M.S. Challenger; the Rumford Medal to Mr. Pierre Jules César Janssen, For. Mem. R.S., for his numerous and important researches in the radiation and absorption of light, carried on chiefly by means of the spectroscope. The medals will be presented at the anniversary meeting of the Society on the 3 oth inst. It is hoped that the two eminent Frenchmen named in the foregoing list will be able to appear in person on the day appointed.

THE store-houses, workshops, and studies of zoology of the Jardin des Plantes, Paris, have been recently removed to a new and most commodious building in the rue Buffon, where there is ample space for scientific work of every kind. Plans have likewise been made for the erection of a large new building in front of the "Galerie," in order to give more space for the exhibition of the general collection of zoology.

RUSSIAN newspapers announce the death of M. Chekanoffsky, who, exiled in Siberia, has spent more than ten years in the 